\title{
Metode Teman Sebaya (Peer Group) Berdampak Terhadap Persepsi Remaja Tentang Kesehatan Reproduksi
}

\author{
Cory C. Situmorang ${ }^{1}$, Maria Wattimena, ${ }^{2}$ Fredrika N. Losu ${ }^{3}$ \\ ${ }_{1,2}$ Dosen Prodi D.III Kebidanan Poltekkes Kemenkes Sorong \\ ${ }^{3}$ Poltekkes Kemenkes Manado

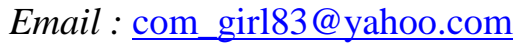

Naskah Diterima : Januari 2019 Disetujui : Februati 2019 Publikasi : Juli 2019

\begin{abstract}
ABSTRAK
Latar Belakang : Kesehatan reproduksi merupakan masalah yang penting untuk mendapatkan perhatian terutama dikalangan remaja.

Tujuan : penelitian ini untuk mengetahui apakah terdapat perbedaan persepsi siswa/siswi SMA Negeri 1 Kota Sorong tentang kesehatan reproduksi dengan menggunakan metode peer group (teman sebaya). Jenis penelitian adalah studi Quasi Experiment dengan rancangan pre test and post test one group desaign, sampel yang digunakan adalah 30 responden.

Hasil : penelitian menunjukkan bahwa, diperoleh nilai $\mathrm{P} 0,000<0,05$ maka Ha diterima, artinya terdapat perbedaan persepsi siswa/siswi SMA Negeri 1 Kota Sorong tentang kesehatan reproduksi dengan metode peer group (teman sebaya).

Kesimpulan : Penelitian ini menyimpulkan, metode peer group dapat digunakan bukan hanya untuk member informasi tentang kesehatan reproduksi saja melainkan bisa dimanfaatkan dalam proses pembelajaran.
\end{abstract}

Kata Kunci : Layanan Informasi; Metode Peer Group; Kesehatan Reproduksi Remaja

\section{PENDAHULUAN}

Masa remaja adalah masa yang penuh permasalahan, permasalahan remaja yang ada saat ini sangat kompleks terutama masalah kesehatan reproduksi yang sering dialami remaja meliputi: masalah gizi, masalah seks dan seksualitas, kehamilan remaja dan kehamilan yang tidak diinginkan (KTD), aborsi tidak aman, penyakit menular seksual (PMS) dan HIV/AIDS, maupun kemandulan. Remaja pun sering dihadapi masalah yang tidak kala penting diperhatikan lebih mendalam seperti remaja yang tidak mengetahui cara-cara pubertas, kesehatan reproduksi remaja, dan cara merawat organ reproduksi. (1) Pada studi pendahuluan yang dilakukan oleh peneliti dengan mewawancarai 10 siswi, didapatkan hasil bahwa dari 10 siswi terdapat 3 siswi tidak mengetahui tentang konsep kesehatan reproduksi, sedangkan 7 siswi lainnya telah mengetahui konsep dari kesehatan reproduksi. Dari 7 siswi yang telah mengetahui konsep kesehatan reproduksi menyatakan bahwa informasi yang telah mereka ketahui tersebut bersumber dari mata pelajaran Life Skill 
Education dan biologi yang telah di ajarkan di sekolah. Para siswi tidak memiliki inisiatif untuk mengakses informasi secara mendalam mengenai konsep kesehatan reproduksi melalui media lainnya selain mata pelajaran yang telah diajarkan di sekolah seperti dengan cara bertanya kepada teman sebaya atau keluarga, mengakses informasi secara langsung melalui media cetak atau elektronik, serta menyatakan belum pernah mendapat sosialisasi secara langsung oleh tenaga kesehatan selama bersekolah di SMA N 1 Kota Sorong. Dewasa ini, pada umumnya media elektronik serperti handphone yang merupakan media yang sangat dekat serta hampir di gunakan setiap hari oleh siswi tidak digunakan secara maksimal untuk mengakses informasi yang bermanfaat bagi mereka, salah satunya adalah informasi mengenai konsep serta perilaku kesehatan reproduksi. Penggunaan media ini lebih dimanfaatkan untuk mengakses situs-situs sosial media hiburan. Berdasarkan paparan tersebut, maka peneliti tertarik untuk melakukan penelitian mengenai Pengaruh Layanan Inormasi Kesehatan Reproduksi Remaja Oleh Teman Sebaya (Peer Group) Terhadap Persepsi Kesehatan Reproduksi Remaja di SMA Negeri 1 Kota Sorong.

METODE
Jenis penelitian adalah studi Quasi Experiment dengan rancangan pre test and post test one group desaign adalah desain yang dilakukan dua kali penilaian yaitu sebelum eksperimen (pre test) dan sesudah eksperimen (post test) $^{(\mathbf{2})}$. Populasi diambil dari keseluruhan objek penelitian. Populasi dalam penelitian ini adalah seluruh siswa SMA Negeri 1 Kota Sorong maka jumlah sampel yang digunakan adalah 30 siswa, yang diambil dari satu kelas. Penelitian ini dilaksanakan di SMA Negeri 1 Kota Sorong dengan studi pendahuluan dilakukan pada bulan April 2017 dan pengambilan data pada bulan Juli 2017. Penelitian ini dilaksanakan oleh peneliti dengan 2 kali pertemuan selama 2 minggu. Instrument yang digunakan adalah kuesioner. Kuesioner ini berbentuk pertanyaan tertutup (closed ended) dimana dalam pertanyaan ini sudah diberikan jawaban $^{(3)}$. Kuesioner ini diisi oleh responden dan digunakan untuk mengukur persepsi, dengan pertanyaan sebanyak 30 pertanyaan. Analisis data dengan menggunakan univariat dan bivariat, uji statistik yang digunakan untuk uji normalitas data dalam penelitian ini adalah One Sample Kolmogrov-Smirnov test dengan menggunakan taraf signifikansi 0,05 . Data dinyatakan berdistribusi normal 
jika signifikansi lebih besar dari 5\% atau 0,05. Selanjutnya peneliti perlu melakukan uji kesamaan (homogenitas) beberapa bagian sampel, yaitu seragam tidaknya variansi sampel-sampel yang diambil dari populasi yang sama. Uji homogenitas bertujuan untuk memastikan bahwa kelompok-kelompok yang dibandingkan merupakan kelompok-kelompok yang homogen. Uji homogenitas menggunakan uji $\mathrm{F}$ dengan taraf signifikansi 0,05. Data dinyatakan homogeny jika signifikansi lebih besar dari 5\% atau 0,05. Setelah uji asumsi dasar terpenuhi maka dilanjutkan dengan uji hipotesa menggunakan paired samples t-test, namun jika uji asumsi dasar tidak terpenuhi maka akan digunakan uji Kruskal Wilis

\section{HASIL}

Distribusi Karakteristik Responden Berdasarkan Jenis Kelamin, terbanyak responden dengan jenis kelamin perempuan $(66,67 \%)$ dibandingkan dengan responden laki-laki (33,33\%), Berdasarkan Sumber Informasi Pengetahuan Kesehatan Reproduksi berdasarkan sumber informasi paling banyak sudah pernah mendapatkan informasi kesehatan reproduksi lebih banyak dibadingkan dengan yang belum pernah mendapatkan informasi kesehatan. Uji statistik dengan menggunakan paired samples $t$-test, diperoleh nilai p 0,001 <
0,05 , artinya terdapat perbedaan persepsi siswa-siswi SMA Negeri 1 Kota Sorong tentang kesehatan reproduksi dengan metode peer group (teman sebaya).

\section{PEMBAHASAN}

Responden dari penelitian ini pada umumnya adalah remaja berjenis kelamin wanita dengan persentasenya yaitu $66,67 \%$, dibandingkan dengan remaja yang berjenis kelamin laki-laki 33,33\%. Jumlah remaja perempuan lebih banyak daripada jumlah remaja laki-laki maka remaja perempuan lebih banyak peluang menjadi peer group yang dilatih menjadi peer educator dalam penyampaian pendidikan kesehatan reproduksi. Gangguan kesehatan reproduksi bisa dialami baik pria maupun wanita namun pada kenyataannya banyak penyakit yang terjadi pada wanita, umumnya gangguan kesehatan reproduksi dikarenakan masalah-masalah yang tidak diduga karena beberapa wanita yang seringkali menyepelekan kebersihan alat reproduksi sehingga mengalami gangguan karena alat reproduksi wanita sangat sensitive dan dekat dengan anus sehingga sangat rentan terkena berbagai infeksi ataupun penyakit yang berdampak pada kematian bila tidak ditanggulangi dengan cepat dan tepat. Kesehatan reproduksi bergantung pada bagaimana cara merawatnya mulai dari 
gaya hidup, pola makan, hingga perilaku yang berhubungan dengan kesehatan reproduksi secara menyeluruh. Bukan hanya perawatan alat genetalia saja yang perlu diperhatikan wanita namun juga semakin muda perempun melakukan hubungan seks, maka akan semakin meningkat resiko terkena kanker servik dan penyakit lainnya. (4) Karakteristik lain adalah pengalaman remaja memperoleh pengetahuan kesehatan reproduksi dan sumber informasi remaja memperoleh pengetahuan kesehatan reproduksi. Dimana penelitian ini ada remaja yang menyatakan bahwa tidak pernah mendapat informasi kesehatan reproduksi remaja yaitu sebanyak 7 siswa (23,33\%), hasil penelitian ini juga menunjukkan bahwa sebagian besar pernah memperoleh pendidikan kesehatan reproduksi yaitu informasi terbanyak didapatkan dari sosial media sebanyak 19 siswa $(63,33 \%)$.

Hasil penelitian diatas terbukti dengan sumber informasi tentang kesehatan reproduksi didapatkan dari berbagai media baik media cetak maupun media elektronik termasuk pada sosial media yang paling banyak digunakan sebagai sumber informasi kesehatan reproduksi. Minimnya informasi mengenai kesehatan didapatkan remaja dan terkedang informasi yang didapatkan kurang akurat menyebabkan ketidakmampuan remaja dalam menjaga kesehatan reproduksinya, sehingga dapat meningkatkan risiko terkena penyakit menular seksual terutama pada remaja yang aktif secara seksual. Penyakit ini dapat berupa keputihan, Klamidia, Gonorea, hingga HIV/AIDS. Apabila dibiarkan, penyakit tersebut dapat mengakibatkan infeksi lebih lanjut dan membahayakan dirinya. (5) Dari hasil uji hipotesa diperoleh bahwa terdapat perbedaan persepsi siswa-siswi SMA Negeri 1 Kota Sorong tentang kesehatan reproduksi dengan metode peer group (teman sebaya), ini berarti bahwa menggunakan metode peer group memberikan pengaruh yang positif untuk meningkatkan persepsi remaja tentang kesehatan reproduksi. Hal ini didukung oleh penelitian yang menyatakan, bahwa penyampaian pendidikan kesehatan reproduksi oleh kelompok sebaya (peer group) sangat berpengaruh terhadap peningkatan pengetahuan kesehatan reproduksi remaja di Kelurahan Kemiri Muka Depok. Hal ini dibuktikan dengan uji hipotesis menggunakan uji $\mathrm{t}$, nilai $\mathrm{t}$ hitung sebesar 5,984 dengan $\mathrm{p}<0,05$ yaitu 
p sebesar 0,001. Menunjukkan ada pengaruh yang signifikan yaitu dengan terjadinya peningkatan pengetahuan kesehatan. (6) Kelompok sebaya (peer group) adalah kelompok anak-anak atau pemuda yang berumur sama atau berasosiasi dan mempunyai kepentingan umum tertutup, seperti persoalanpersoalan anak-anak umur sekolah sampai dengan masa remaja (adolescence). Kelompok sebaya merupakan kelompok sosial dimana masing-masing anggota terjalin hubungan yang erat dan bersifat pribadi. (7)

Remaja mempunyai kecenderungan untuk berinteraksi dengan teman sebayanya dan mengadopsi informasi yang diterima oleh teman-temannya, tanpa memiliki dasar informasi yang signifikan dari sumber yang lebih dapat dipercaya. Hal ini karena remaja lebih banyak berada di luar rumah bersama dengan temanteman sebayanya, maka dapatlah dimengerti bahwa interaksi teman sebaya membawa pengaruh lebih besar daripada pengaruh keluarga pada sikap, pembicaran, penampilan dan perilaku.

Dalam kelompok sebaya remaja mendiskusikan tentang masalah dan mereka menemukan sesuatu yang tidak mereka temukan dirumah. Hubungan yang bersifat pribadi menyebabkan seseorang dapat mencurahkan hatinya kepada temantemannya baik sesuatu yang menyenangkan atau sesuatu yang menyedihkan. Dalam kelompok ini terjadi kerja sama, tolong-menolong, akan tetapi sering terjadi persaingan dan pertentangan. Pengaruh yang kuat dari kelompok teman sebaya pada masa remaja sebagian berasal dari keinginan remaja untuk dapat diterima oleh kelompok dan sebagian lagi dari kenyataan bahwa remaja menggunakan waktu lebih banyak dengan teman sebaya. Usaha mencari identitas untuk menjelaskan siapa dirinya dan peran dalam masyarakat menyebabkan remaja banyak berada di luar rumah bersama teman sebaya (peer group). Peer group atau kelompok teman sebaya menjadi suatu sarana sekaligus tujuan dalam pencarian jati diri mereka. Penelitian ini menggabungkan antara penyampaian pendidikan kesehatan oleh kelompok sebaya (peer group) dengan metode ceramah dengan menggunakan bantuan materi menggunakan leaflet, tanya-jawab dengan peneliti. Hal ini sesuai dengan pernyataan. (9) bahwa dalam memilih metode pendidikan kelompok dan pendidikan kesehatan, harus diingat 
besarnya kelompok sasaran serta tingkat

pendidikan formal dari sasaran.

\section{KESIMPULAN}

Berdasarkan hasil dan pembahasan maka dapat disimpulkan bahwa terdapat perbedaan persepsi siswa-siswi SMA

Negeri 1 Kota Sorong tentang kesehatan reproduksi dengan metode peer group (teman sebaya).

\section{DAFTAR PUSTAKA}

1. Efendi D. Hubungan Tingkat Pengetahuan Tentang Kesehatan Reproduksi Dengan Tingkat Kecemasan Menghadapi Pubertas Pada Remaja di SLTP Muhammadiyah 3 Yogyakarta. 2010.

2. Rizema P. Statistik Kesehatan Belajar Mudah Teknik Data dalam Penelitian Kesehatan (Plus Aplikasi Sofware SPSS). Yogyakarta: Mitra Cendekia Press; 2012.

3. S. Notoatmodjo. Pendidikan dan Perilaku Kesehatan. Jakarta: Rineka Cipta; 2005.

4. Nursalam. Konsep dan Penerapan Metodologi Pendidikan Ilmu Keperawatan Pedoman Skripsi, Tesis dan Istrument Penelitian Keperawatan. Jakarta: Sagung Seta; 2009.

5. Soetjiningsih. Tumbuh Kembang Remaja dan Permasalahannya. Jakarta: Sagung Seto; 2007.

6. Achjar, H.A. K. Asuhan Keperawatan Keluarga. Jakarta: Sagung Seta; 2010.

7. Sarwono S. Psikologi Remaja. Jakarta: Raja Grafindo Persada; 2008.

8. Handayani U. Laporan Praktik Pengalaman Lapangan di SMP Negeri 2 Kasihan Bantul. 2011.

9. Tome A. Pengaruh Pemberian Pendidikan Kesehatan Terhadap Tingkat Pengetahuan dan Sikap Keluarga Dalam Perawatan Usia Lanjut Dirumah Di Kelurahan Ngupasan Wilayah Kerja Puskesmas Gondomanan Yogyakarta 2013. 2012. 